\title{
Sound production of red grouper Epinephelus morio on the West Florida Shelf
}

\author{
Misty D. Nelson ${ }^{1, *}$, Christopher C. Koenig ${ }^{2}$, Felicia C. Coleman ${ }^{2}$, David A. Mann ${ }^{1}$ \\ ${ }^{1}$ College of Marine Science, University of South Florida, St. Petersburg, Florida 33701, USA \\ ${ }^{2}$ Florida State University Coastal and Marine Laboratory, 3618 Coastal Highway, St. Teresa Beach, Florida 32358, USA
}

\begin{abstract}
Passive acoustic and digital video recordings were used to investigate sonic activity and behavior of red grouper Epinephelus morio on the West Florida Shelf. Red grouper were found to produce a unique series of low-frequency (180 Hz peak) pulses consisting of 1 to 4 brief $(0.15 \mathrm{~s})$ broadband pulses and a 0.5 to $2 \mathrm{~s}$ growl (short call); occasionally these were followed by a rapid series of 10 to 50 broadband pulses (pulse train). Sound production was observed throughout the day and night, but most sounds occurred between sunrise and sunset, with a noticeable increase during late afternoon. Behaviors associated with sound production included solitary male activity and courtship interactions, indicating that sound production is likely related to spawning activity. Thus, passive acoustics could be an effective tool in monitoring red grouper reproduction and defining critical habitat of a keystone species.
\end{abstract}

KEY WORDS: Epinephelidae $\cdot$ Acoustics $\cdot$ Video $\cdot$ Fish behavior $\cdot$ In situ observations $\cdot$ Diel periodicity $\cdot$ Gulf of Mexico

\section{Resale or republication not permitted without} written consent of the publisher

\section{INTRODUCTION}

Red grouper Epinephelus morio are long-lived members of the family Epinephelidae, and are found throughout the western North Atlantic and Gulf of Mexico. They are commercially important, representing $76 \%$ of the United States grouper fishery (NMFS 2011). Although extensive life-history information exists, largely from fishery catches, little is known about the behavior of red grouper in situ. Recent evidence indicates that red grouper modify their local environment by excavating sediments to expose rocky

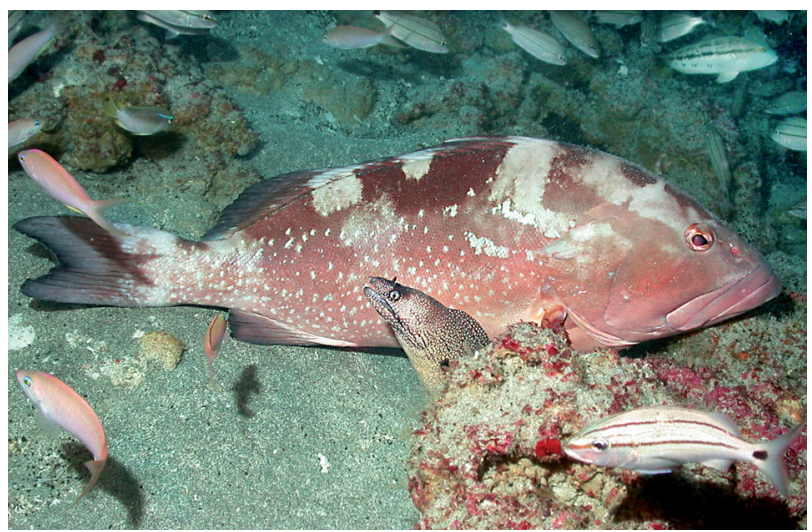

Sound production in red grouper Epinephelus morio is useful for monitoring their distribution and behavior.

Photo: National Undersea Research Center, University of North Carolina, Wilmington, USA

depressions on the seafloor (Coleman et al. 2010); this 'ecosystem engineering' creates habitat for a wide variety of species, and red grouper may serve as a keystone species in the Gulf of Mexico (Coleman \& Williams 2002, Coleman et al. 2010).

Red grouper larvae are pelagic, and juveniles can be found on nearshore reefs and grass beds, and in estuaries (Moe 1969, Burgos et al. 2007). With the onset of sexual maturity, typically around $5 \mathrm{yr}$ of age, individuals migrate into deeper waters of the continental shelf and shelf edge (Moe 1966, 1969). Adults exhibit strong site fidelity and are not thought to undertake longdistance seasonal migrations (Coleman et al. 2010). Like many epinephelids, red grouper are protogynous hermaphrodites. Female to male transition occurs between 5 and $10 \mathrm{yr}$ of age, and by age 15 the male:female 
sex ratio becomes equal (Moe 1969, Jory \& Iversen 1989). The red grouper reproductive season extends from January through July, with a peak in spawning activity occurring between March and May (Moe 1969, Johnson et al. 1998, Collins et al. 2002, Burgos et al. 2007). Limited findings suggest that, unlike many grouper species, red grouper do not form large spawning aggregations (Brule et al. 1999); rather, they form small polygynous groups (Coleman et al. 1996) and remain in relatively close proximity to limestone outcroppings or rocky depressions excavated in the sandy bottom (Moe 1969, Bullock \& Smith 1991, Coleman \& Williams 2002, Scanlon et al. 2005, Coleman et al. 2010). Red grouper spawning behavior is believed to be similar to that of some Cephalopholis species (Teleostei: Epinephelidae), including coney C. fulva and graysby $C$. cruentatus, which has been described as nonmigratory polygynous pair-spawning (Sadovy et al. 1994, Coleman et al. 1996). Details of red grouper spawning behavior, however, remain largely unknown.

Red grouper are among the ever-increasing number of fish species known to produce sounds (Fish \& Mowbray 1970). The mechanism of red grouper sound production is believed to be similar to the closely related Nassau grouper Epinephelus striatus, which generates sounds by rapidly contracting bilateral muscles behind the opercles, causing the swim bladder to vibrate (Hazlett \& Winn 1962). Fish \& Mowbray (1970) describe a simple 'boom' sound generated during competitive feeding among several captive adult red grouper. They also describe sounds of numerous other epinephelid fishes, including Nassau grouper, goliath grouper $E$. itajara, red hind E. guttatus, rock hind E. adscensionis, speckled hind E. drummondhayi and Warsaw grouper Hyporthodus nigritus. However, most observations were made by mechanical or electrical stimulation of captive individuals, which provides little insight into the full repertoire of possible sounds and the associated behaviors.

Fishes produce sounds in a number of situations, including agonistic encounters (Ladich 1997), territorial defense (Myrberg 1972, Amorim et al. 2003), courtship (Myrberg et al. 1986, McKibben \& Bass 1998) and spawning (Lobel 1992, Mann et al. 1997). Peaks in calling activity have been linked to reproductive behavior in many families, including Pomacentridae (Mann \& Lobel 1995), Gobiidae (Malavasi et al. 2009), Batrachoididae (McKibben \& Bass 1998), Percidae (Johnston \& Johnson 2000), Holocentridae (Winn et al. 1964) and Sciaenidae (Mok \& Gilmore 1983, Connaughton \& Taylor 1995, Locascio \& Mann 2008). Limited observations of goliath grouper have shown that males produce low-frequency booms during presumed courtship behavior (Colin 1990, Mann et al. 2009) whereas red hind males produce low-frequency pulsed sounds during territorial patrols and interactions with females (Mann \& Locascio 2008). Little information exists, however, about behavior associated with sound production of red grouper.

Several studies in the 1960s utilized underwater acoustic-video systems to observe sound production in fishes, primarily to identify species-specific sounds (Steinberg et al. 1965, Cummings et al. 1966). More recently, laboratory studies have used video to observe sound production and behavior in captive fishes (McKibben \& Bass 1998, Malavasi et al. 2009, Maruska \& Mensinger 2009). Commercially available digital recorders, microcomputers and high-capacity data storage devices have greatly expanded the potential applications of video technology. The present study used passive acoustic recordings combined with simultaneous digital video recordings to explore the behavior of red grouper in their natural environment, focusing on sound production and its potential relationship to spawning. The primary objectives were to: (1) describe sounds produced by red grouper in situ, (2) relate sound production to specific behaviors, and (3) describe the daily periodicity of red grouper sound production.

\section{MATERIALS AND METHODS}

Study sites. The study was conducted in the Madison-Swanson (MS) and Steamboat Lumps (SL) marine reserves on the West Florida Shelf, in water depths of 60 to $90 \mathrm{~m}$ (Fig. 1). These reserves were established in 2000 and are closed year-round to all commercial and recreational reef fishing (GMFMC 2008). Although the reserves were implemented primarily to reduce fishing pressure on aggregations of gag Mycteroperca microlepis and scamp M. phenax (Coleman et al. 2004), red grouper also occur within reserve boundaries (Scanlon et al. 2005, Coleman et al. in press). In MS, red grouper are commonly associated with lowrelief carbonate rock outcroppings in the sandy bottom; in SL, red grouper are typically found in rockfilled excavations in sandy bottom, which can be observed in high-resolution sidescan sonar images (Coleman et al. 2010, in press).

Field operations were carried out aboard the MV 'Liberty Star' from 5 to 15 May 2008. Sidescan bathymetry maps were used to guide the ship to areas likely to have red grouper, primarily the area east of Stu's Ridge in MS and the north-central portion of SL (Coleman et al. in press). A Deep Ocean Engineering Phantom S2 remotely operated vehicle (ROV) was used to provide realtime video transmission to the control ship, allowing for verification of red grouper presence. This initial assessment enabled placement of recorders close to fish. 


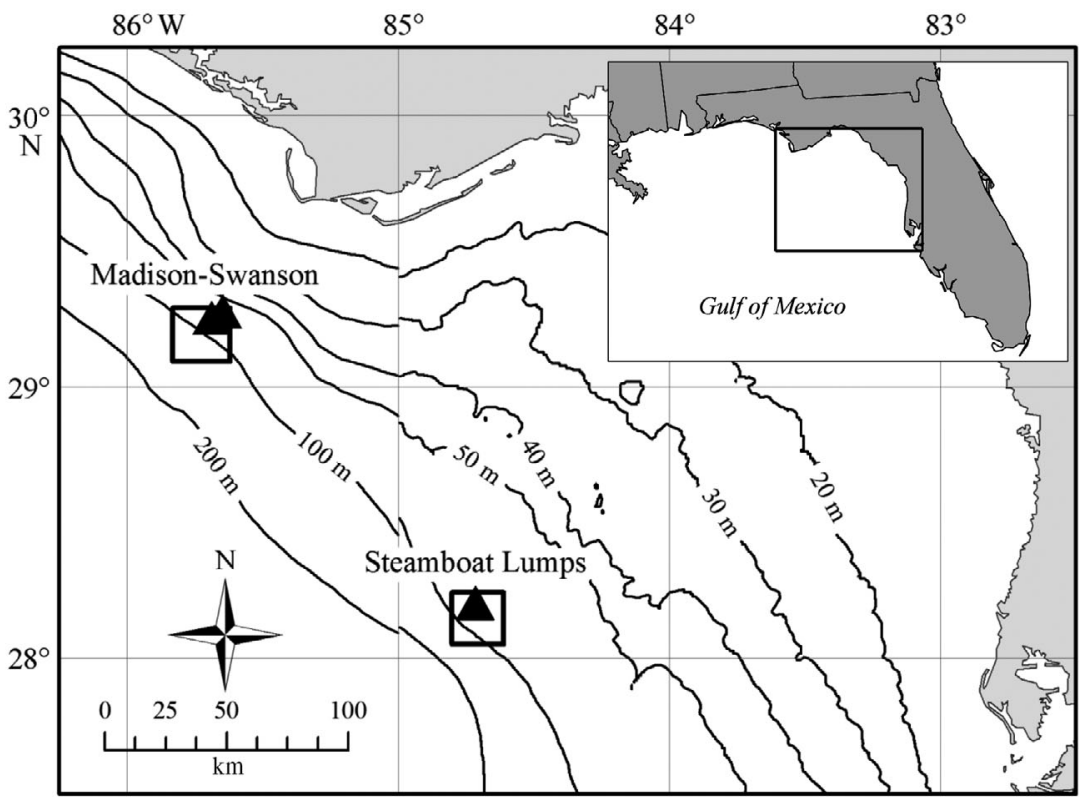

Fig. 1. Locations of marine reserves (squares) on the West Florida Shelf where acoustic and video recorders were deployed. ( $(\mathbf{\Delta})$ : deployment sites

the ROV to have resident red grouper), with the cameras directed towards the pit. Three deployments were made at SL: (1) 5 units around a pit with a resident male $\left(28^{\circ} 12.3^{\prime} \mathrm{N}, 84^{\circ} 43.0^{\prime} \mathrm{W} ; 75 \mathrm{~m}\right.$ depth); (2) 2 units around a second pit with a resident male $\left(28^{\circ} 12.1^{\prime} \mathrm{N}\right.$, $84^{\circ} 43.0^{\prime} \mathrm{W}$; $70 \mathrm{~m}$ depth); and (3) 2 units around a small pit with a female present, approximately $20 \mathrm{~m}$ southwest of the second male pit. Two deployments were made along Stu's Ridge in MS (29 $15.2^{\prime} \mathrm{N}$, $85^{\circ} 41.3^{\prime} \mathrm{W}$ ), with 3 units at a depth of $64 \mathrm{~m}$ and 2 units at $66 \mathrm{~m}$. All units recorded audio and video continuously for up to $24 \mathrm{~h}$.

Additional custom Digital SpectroGram (DSG) audio recorders were deployed to provide a longer time-series for periodicity analyses. These units consisted of a cylindrical PVC housing, a single HTI-96-MIN hydrophone (sensitivity $=-186 \pm 1 \mathrm{~dB}$ re $1 \mathrm{~V} \mu \mathrm{Pa}^{-1}$ between 2 and $37 \mathrm{kHz}$ ), a micro-computer and a

Video and acoustic recorders. Autonomous recorders deployed at selected sites within the marine reserves captured digital video using low-light, wide-angle, black and white cameras. Custom cylindrical PVC housings with a clear acrylic plate covering one end were mounted on aluminum tripods weighted with lead. Four housings contained Chasecam PDR100 Solid State Digital Recorders (Chase Product Development) with 4 internal lithium AA batteries; the fifth contained an Archos 605 WIFI Portable Media Player. Additionally, each unit had an SSC-108WXXB .0003 Lux Low Light B/W 420 Line Board Lens camera (Advance Security Products) mounted to the acrylic plate. Two High Tech HTI-96-MIN Series hydrophones (sensitivity $=-164 \pm 1 \mathrm{~dB}$ re $1 \mathrm{~V} \mu \mathrm{Pa}^{-1}$ between 2 and $37 \mathrm{kHz}$ ) were also connected to each video housing unit, the first directly attached to the back plate and the second attached to a $1.4 \mathrm{~m}$ tether. The 2 channels of audio were recorded continuously at a sample rate of $44.1 \mathrm{kHz}$ and, along with video data, were saved to A-DATA Speedy 32 GB compact flash memory cards (A-DATA Technology), except in the case of the Archos recorder, which had 30 GB internal memory. Each unit was powered by $8 \mathrm{D}$-cell batteries connected in series. Foam padding was packed into each housing prior to sealing to prevent equipment movement or damage. Silica packs were used to absorb moisture and prevent condensation from interfering with the video.

Video recorders were placed manually by National Undersea Research Center (NURC) technical divers around active red grouper pits (i.e. pits observed by circuit board, and were powered by 6 D-cell alkaline batteries. Single-channel audio was recorded at a sample rate of $50 \mathrm{kHz}$ and was saved on Patriot 16 GB SanDisk secure digital flash memory cards. Individual recording units were attached to anchored line using steel gangion snaps and cable ties placed $\sim 3 \mathrm{~m}$ above the anchor, with a single float $30 \mathrm{~m}$ above the unit to prevent sinking, as well as surface buoys for relocation and retrieval (Fig. 2). Units were deployed from the deck of the ship in the general vicinity of active grouper pits based on GPS locations. In SL, 4 DSG recorders were placed 100 to $200 \mathrm{~m}$ apart, 200 to $300 \mathrm{~m}$ north of video recorder locations, at depths of 72 to $90 \mathrm{~m}$. These units recorded for $5 \mathrm{~d}$ with a duty cycle of $2.5 \mathrm{~min}$ every $10 \mathrm{~min}$. In MS, 3 DSG recorders were placed 150 to $200 \mathrm{~m}$ apart, in an area of low-relief hardbottom $\sim 5 \mathrm{~km}$ northeast of the video recorders at Stu's Ridge, in water depths of 57 to $60 \mathrm{~m}$. These units recorded for $2 \mathrm{~d}$ with a duty cycle of $8 \mathrm{~min}$ every $10 \mathrm{~min}$.

Analysis of sounds. Preliminary identification of red grouper sounds was made by the simultaneous occurrence of a recorded sound and at least one red grouper visible in video footage. This identification was further supported by an arrival-time delay of $\sim 0.9 \mathrm{~ms}$ between the attached and tethered hydrophones, indicating that the sound originated in front of the video housing.

Audio portions of video recordings were used for descriptive analyses, as these units were placed in the closest proximity to fish and therefore contained the clearest and most consistent sounds. Audio tracks were separated from each MPEG video file using Ulead 




Fig. 2. Diagram of DSG audio recorder setup in the water column, showing relative locations of recorder (r), mid-water float (mwf) and surface floats (sf). Note: distances not to scale

VideoStudio 11.0 (Corel, www.ulead.com) and saved as 16 bit WAV files. Video files recorded during nighttime hours were often highly compressed and were manually divided into $2 \mathrm{~h}$ sections prior to analysis. Files longer than $10 \mathrm{~h}$ were split into 2 separate files using Servant Salamander 2.51 (ALTAP, www.altap.cz) before they could be opened in Ulead.

Each WAV file was initially analyzed using Raven Pro 1.3 (Cornell Laboratory of Ornithology, Ithaca, NY, USA, www.birds.cornell.edu/raven). Spectra were generated with a Hann window and discrete Fourier transform (DFT) size of 4096 samples, and frequencies from 0 to $1200 \mathrm{~Hz}$ were viewed in $30 \mathrm{~s}$ windows. Individual red grouper sounds were manually selected (selection boxes included $\sim 2 \mathrm{~s}$ beyond the end of each call to serve as a measure of background noise) and saved as separate 16 bit WAV files with a sample rate of $44.1 \mathrm{kHz}$. The Batch Channel Exporter was then used to create separate WAV files for each channel.

MATLAB 7.7 (www.mathworks.com) was used to resample each call to $4410 \mathrm{~Hz}$. All video recorders were calibrated by recording $0.1 \mathrm{~V}$ peak test sine waves at $10,20,50,100,150,200,400,700,1000$ and $1500 \mathrm{~Hz}$, and determining the frequency response. For each recorder, the unique frequency response was used to create a custom finite-duration impulse response normalization filter, which was then applied to the resampled WAV files from that recorder. Signal-to-noise ratios (SNRs) were calculated for each corrected file, and all files with SNR $>6 \mathrm{~dB}$ were included in sub- sequent analyses. Start-time and RMS amplitudes were then generated for each file. Files from the same site and time were categorized as replicates (i.e. the same call was recorded on more than one unit), and the call with the highest RMS amplitude for each replicate was included in final analysis.

Additional manual analysis in Raven was performed on each call: spectra (Hann window, DFT size: 1024 samples, 0 to $2205 \mathrm{~Hz}$ ) were used to generate peak frequency measurements. Waveform plots were used to measure durations and inter-pulse intervals. Custom MATLAB programs were used to calculate all other measurements, including amplitudes, bandwidths and sound pressure levels (SPLs).

Behavioral analysis. Analysis of video footage associated with sounds was performed using Ulead VideoStudio. Video from all recorders was visually inspected for each sound event included in the descriptive analysis. Although only the best replicates were included in the sound analysis, all replicates were included in the behavioral analysis, as fish were not necessarily visible in footage from all units. Observations were made for at least $10 \mathrm{~s}$ before and after each sound, and included the number of fish observed and a general description of behavior at the time of sound production. Sex of individuals was noted if possible, based on distinct display coloration patterns; males have darkening along the dorsum, and females exhibit several broad white vertical bands along the body (Coleman et al. in press). Behavioral observations were combined and summarized for each sound event.

Periodicity analysis. Periodicity of sound production was measured by manually browsing spectrograms from DSG recordings using Raven (Hann window, DFT $=4096$ samples, $0-1000 \mathrm{~Hz}$, 30 s increments). Each spectrogram was visually analyzed, and all red grouper sounds were logged, generating a total number of calls recorded for each file. Of 3644 files recorded, 1002 were excluded from analysis because background noise was present at levels likely to prevent detection of red grouper calls. Engine noise from the 'Liberty Star' was the largest contributor to background noise, although abrasion of the PVC housings by the steel gangions also produced intermittent noise. Call rates were calculated by dividing the total number of calls per recording by the duration (e.g. 12 calls in $2.5 \mathrm{~min}=$ 4.8 calls $\mathrm{min}^{-1}$ ). End time was used to categorize each recording into $30 \mathrm{~min}$ and $1 \mathrm{~h}$ time-of-day 'bins' (e.g. 13:00 to $13: 29 \mathrm{~h}, 08: 00$ to $08: 59 \mathrm{~h}$ ). Call rates and counts for each bin were then averaged across all days to calculate mean number of calls and call rate for that time of day. When comparing number of calls from both SL and MS, only calls recorded in the first 2.5 min of MS files were included. 


\section{RESULTS}

\section{Description of sounds}

Red grouper produced a unique series of lowfrequency pulses, and 2 distinct variations were observed: (1) short calls, which comprised 1 to 4 brief pulses followed by a growl (Fig. 3), and (2) pulse train calls, composed of a short call immediately followed by a rapid series of broadband bursts (Fig. 4). Applying the SNR > $6 \mathrm{~dB}$ threshold resulted in 167 short calls, 100 of which were randomly selected for analysis, and 16 pulse trains, all of which were included in analysis $(\mathrm{N}=116)$.

Descriptive statistics were calculated for each call type separately (Table A1 in Appendix 1). Inferential statistical comparisons between call types were not performed because there was no way to know how many individual fish may have been recorded. Fast Fourier transforms (FFTs) of all calls were averaged to generate a mean FFT (Fig. 5), showing a dominant fre- quency at $\sim 180 \mathrm{~Hz}$. This $180 \mathrm{~Hz}$ frequency peak is also reflected in the distribution of peak frequency measurements (Fig. 6). Energy below $50 \mathrm{~Hz}$ is likely due to vessel noise, and inclusion of this energy in peak frequency measurements explains the lower mean peak frequencies $(150 \mathrm{~Hz}$ for short calls, $131 \mathrm{~Hz}$ for pulse trains) reported in Table A1. Six-decibel bandwidth measurements (i.e. the difference between maximum and minimum frequencies having amplitude values within $6 \mathrm{~dB}$ of the peak frequency amplitude; Fig. 7) ranged from 0 to $260 \mathrm{~Hz}$. Centering the maximum $6 \mathrm{~dB}$ bandwidth value of $260 \mathrm{~Hz}$ around the peak frequency of $180 \mathrm{~Hz}$ indicates that most energy lies between 50 and $310 \mathrm{~Hz}$. RMS received SPLs ranged from 110 to $142 \mathrm{~dB}$ re $1 \mu \mathrm{Pa}$ (Fig. 8). Although actual source levels were not obtained, the proximity of recording units to fish suggests that maximum received levels (e.g. $142 \mathrm{~dB}$ re. $1 \mu \mathrm{Pa}, \mathrm{SNR}=37 \mathrm{~dB}$ ) may serve as a close approximation. Call duration increased with the number of pulses, and varied from 1 to $3 \mathrm{~s}$ for short calls and from 3 to $22 \mathrm{~s}$ for pulse trains (Fig. 9).
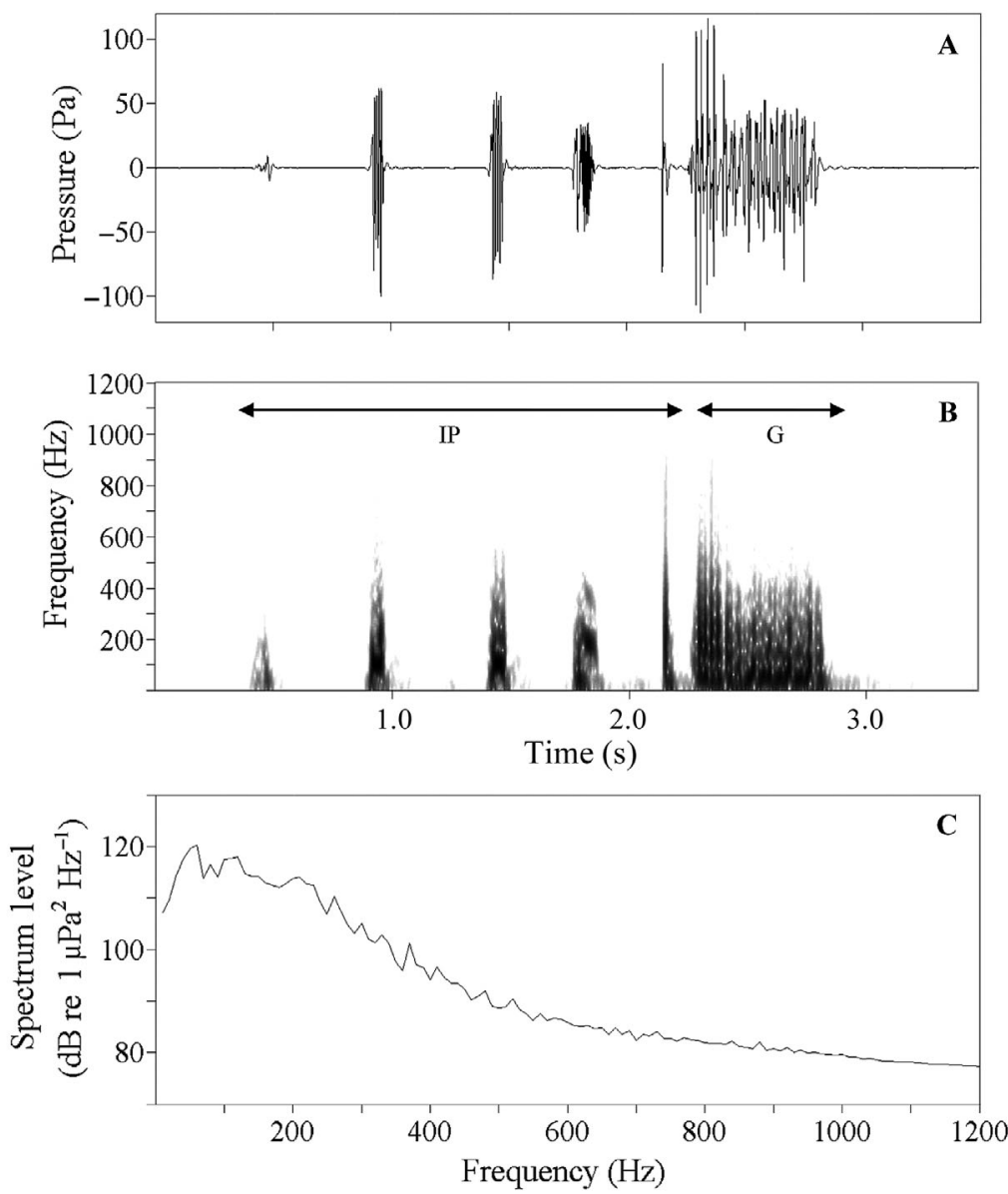

Fig. 3. Epinephelus morio. (A) Waveform, (B) spectrogram (fast Fourier transform $=2048$ samples) and $(C)$ spectrum levels of a typical red grouper short call. Arrows in (B) indicate divisions of call for descriptive measures. IP: introductory pulses; G: growl

\section{Behavior}

Video analysis was performed for all calls included in the descriptive analysis. Of these 116 calls, 56 occurred at night, and an additional 35 had no red grouper visible in video footage. Red grouper behavior observed during the remaining 25 sound production events fell into 2 categories: solitary male activity and courtship interactions. Solitary male activity included patrolling, where a male swam in a repeated pattern around and above a pit $(\mathrm{n}=12$; see Supplementary Video 1 at www.int-res.com/articles/suppl/ b012p097_supp/), and changing color (e.g. darkening of dorsum; $\mathrm{n}=3$; Supplementary Video 2). Short calls and pulse trains were associated with both patrolling and color changes.

Courtship interactions consisted of a male and female swimming together ( $\mathrm{n}=10$; Supplementary Video 3). Rapid swimming with direct physical contact between a male and a female (Supplementary Videos 4 \& 5) occurred during 4 of these interactions, although no spawning was observed. Both short calls and pulse trains were observed during courtship with direct body contact, but only short calls were observed during courtship interactions with no body contact. A summary of each sound-behavior event is given in Table A2 in Appendix 2. 

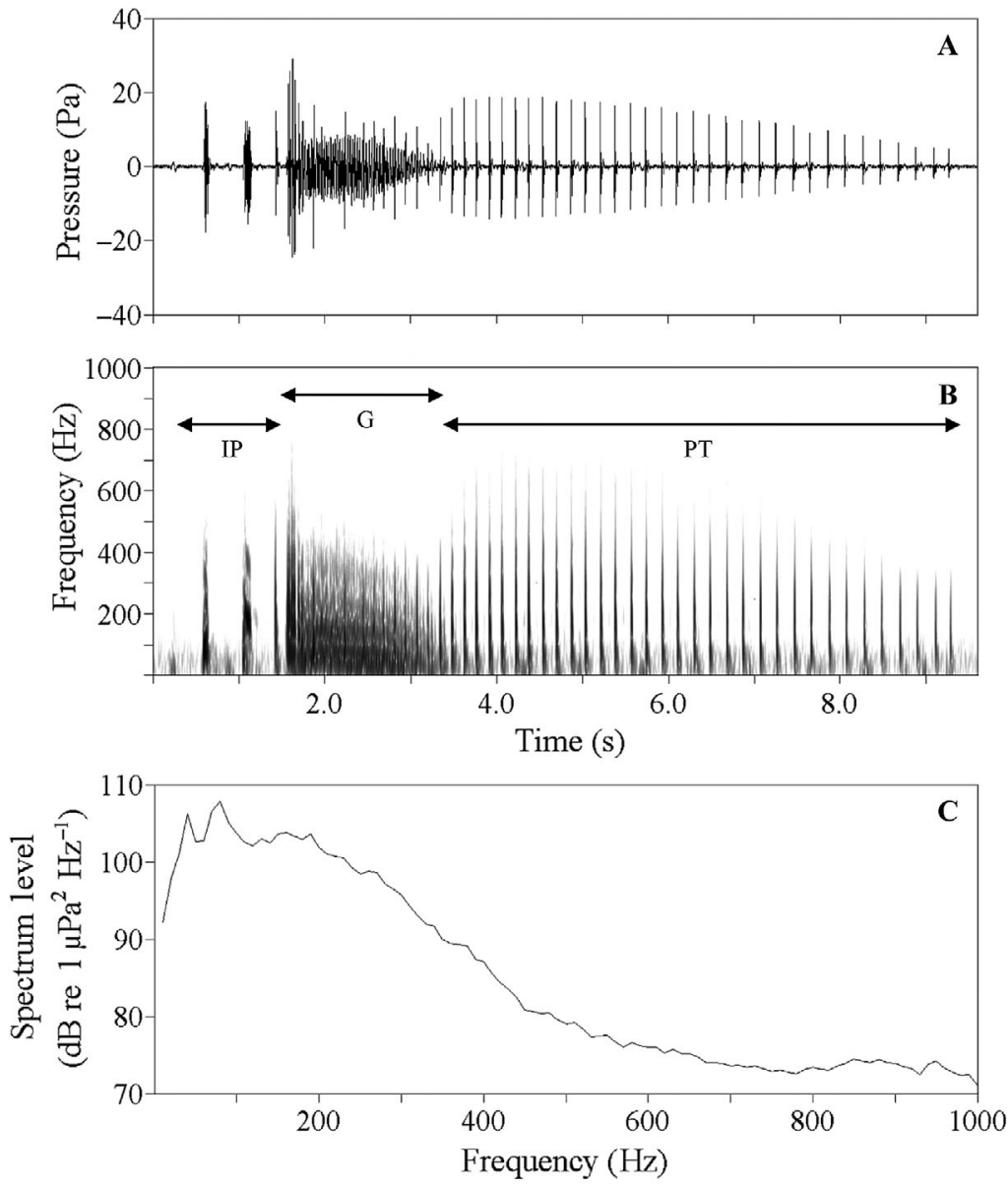

Fig. 4. Epinephelus morio. (A) Waveform, (B) spectrogram (fast Fourier transform $=2048$ samples) and $(C)$ spectrum levels of a red grouper call with a pulse train. Arrows in (B) indicate divisions of call for descriptive measures. IP: introductory pulses; G: growl; PT: pulse train

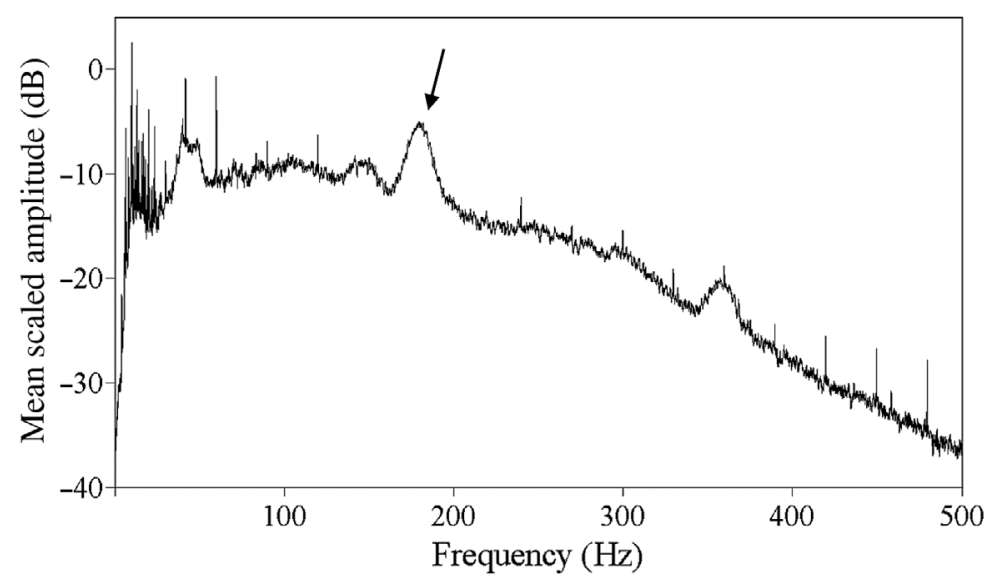

Fig. 5. Epinephelus morio. Average fast Fourier transform (FFT) for red grouper calls $(\mathrm{N}=116)$; arrow denotes peak frequency at $180 \mathrm{~Hz}$. Raw files were resampled to $4410 \mathrm{~Hz}$ and filtered using a finite-duration impulse response correction filter unique to each recorder. The number of points used in each FFT was 110211 , corresponding to the number of points in the longest WAV file; amplitude values for each frequency bin $(0.04 \mathrm{~Hz})$ were scaled to the maximum amplitude in each file above $100 \mathrm{~Hz}$, to ensure scaling to signal peaks rather than noise

\section{Diel periodicity}

Red grouper produced sounds at all times of the day and night and showed a strong diel pattern of sound production (Fig. 10). Calling increased just before dawn, dropped off briefly after sunrise and then increased throughout the day, peaking in the late afternoon before dropping off again after sunset (Fig. 11). Although red grouper in both MS and SL exhibited similar patterns of sonic activity, those in SL had higher daytime calling rates (maximum: $\mathrm{SL}=15$ calls $\min ^{-1}, \mathrm{MS}=9$ calls $\mathrm{min}^{-1}$ ), whereas those in MS had a later afternoon peak (SL: 15:30 h, MS: 17:00 h). Short calls occurred with this daily pattern whereas calls with pulse trains occurred at low levels throughout the day and night (Fig. 12). Without an accurate assessment of fish abundance, statistical comparisons between sites could not be used to determine whether the increase in call rates was due to a greater abundance of fish or to increased activity of a few individuals; it is interesting to note, however, that nighttime call rates were similar at both locations (1 to 2 calls $\mathrm{min}^{-1}$ ).

\section{DISCUSSION}

In situ sounds produced by red grouper were similar to the low-frequency pulsed sounds reported for other free-ranging epinephelids, including Nassau grouper and the closely related red hind (Moulton 1958, Steinberg et al. 1962, 1965), as well as goliath grouper (Mann et al. 2009). The frequency range and pulse duration were consistent with agonistic sounds produced by captive red grouper described by Fish \& Mowbray (1970), but the overall call structure was more complex, consisting of multiple pulses in a characteristic pattern.

No direct observations of coincident spawning and sound production were made. Several explanations are possible: (1) red grouper do not produce sound during the act of spawning; (2) spawning did not occur during the time video recorders were deployed; (3) spawning occurred at night; or (4) spawning occurred during one of the 35 sounds produced while red grouper were not visible in video footage. Additional video analysis is necessary to confirm whether 




Fig. 6. Epinephelus morio. Distribution of peak frequency values for all red grouper calls $(\mathrm{N}=116 ; 10 \mathrm{~Hz}$ bins $)$



Fig. 7. Epinephelus morio. Distribution of $6 \mathrm{~dB}$ bandwidth for red grouper calls $(\mathrm{N}=116 ; 10 \mathrm{~Hz}$ bins), calculated as the difference between maximum and minimum frequencies having amplitude values within $6 \mathrm{~dB}$ of peak frequency amplitude



Fig. 8. Epinephelus morio. Received sound pressure levels (RMS; dB re $1 \mu \mathrm{Pa})$ of red grouper calls $(\mathrm{N}=116 ; 2 \mathrm{~dB}$ bins $)$



Fig. 9. Epinephelus morio. Number of pulses in red grouper short $(\mathrm{O})$ and pulse train $(\nabla)$ calls versus total call duration $(\mathrm{N}=116)$. Duration $=0.22$ Pulses $+0.85, \mathrm{R}^{2}=0.824$

sound production is directly related to spawning. Nevertheless, the fact that red grouper produced sounds during a known peak-spawning month (May) and during courtship displays suggests that sonic activity may be linked to reproductive behavior, as it is in red hind (Mann \& Locascio 2008). Furthermore, crepuscular peaks in calling activity, like those observed for red grouper, have also been observed in several species that typically spawn at dawn and/or dusk (Winn et al. 1964, Mann \& Lobel 1995). Although details of sound production are not known, evening spawning has been observed in tiger grouper Mycteroperca tigris (Sadovy et al. 1994), leopard grouper $M$. rosacea (Erisman et al. 2007), pygmy grouper Cephalopholis spiloparaea (Donaldson 1995), Panama graysby C. panamensis (Erisman et al. 2010), halfmoon grouper Epinephelus rivulatus (Mackie 2007) and dusky grouper E. marginatus (Hereu et al. 2006). If red grouper follow this pattern of evening spawning, then the observed increase in late afternoon calling activity would suggest that sound production is at least a precursor of spawning.

The significance of this work lies in the potential for using passive acoustics as a method for monitoring fish populations and identifying the location of spawning sites over broad spatial and temporal scales (Mok \& Gilmore 1983, Luczkovich et al. 1999, Locascio \& Mann 2008, Sirovic et al. 2009). This is particularly interesting when considering its use in defining areas for fisheries closures. Establishing protected areas contributes to the long-term sustainability of a fishery by reducing fishing pressure on reproductively active individuals, which in turn supports successful spawning and facilitates strong recruitment to the population (e.g. reviews in Halpern \& Warner 2002, Martin et al. 2007). For instance, a red hind spawning aggregation in the US Virgin Islands benefitted from a seasonal closure, with an increase in the size of spawning adults and a favorable shift (recovery) in female:male sex ratio 



Fig. 10. Epinephelus morio. Time series of red grouper sound production at Steamboat Lumps (red) and MadisonSwanson (blue) marine reserves, $7-14$ May 2008. Number of calls represents the mean number of calls for each 10 min time bin for all recorders at each location. For Steamboat Lumps (4 recorders), all calls were included from 2.5 minute files recorded every $10 \mathrm{~min}$; for $8 \mathrm{~min}$ Madison-Swanson recordings (3 recorders), only calls in the first 2.5 min were counted. Gaps in each time series are due to recordings containing high levels of background noise likely to mask detection of red grouper calls; these were excluded from analysis. Shaded areas represent night (sunrise: 05:50 h; sunset: 19:20 h)

Fig. 11. Epinephelus morio. Diel periodicity of red grouper sound production at Steamboat Lumps (red triangles) and Madison-Swanson (blue circles) marine reserves. Mean $\pm \mathrm{SD}$ call rate for all recordings within 30 min time bins. Steamboat Lumps call rates were calculated from $2.5 \mathrm{~min}$ recordings every $10 \mathrm{~min}$; Madison-Swanson values were calculated from 8 min recordings every $10 \mathrm{~min}$. Shaded areas represent night (sunrise: 05:50 $h$; sunset: 19:20 h)

(Beets \& Friedlander 1998, Nemeth 2005). Subsequently, this same aggregation experienced a $60 \%$ increase in stock density and biomass following a permanent year-round closure (Nemeth 2005). Coleman et al. (2000) recommended establishing networks of large marine protected areas (MPAs) for managing species - including red grouper-that may be highly susceptible to overfishing. Similarly, Koenig et al. (2000) emphasized the importance of protecting habitat by establishing reserves, which would then allow researchers to better understand production in unfished areas. The widespread distribution, protracted spawning season and lack of seasonal movement of red grouper make designating effective closures challenging. Large and/or widespread closures are difficult to enforce and are likely to encounter resistance from the fishing industry, whereas small areal closures may not protect sufficient numbers of fish (Halpern 2003, Gaines et al. 2010). Passive acoustic surveys throughout the known range of red grouper-using either towed arrays or autonomous underwater vehiclescould provide a detailed map of their distribution. If sound production proves to be closely linked to spawning behavior, habitat use could then be more clearly defined (Luczkovich et al. 1999). This approach would enable identification of critical habitats and, ultimately, designation of reserves for red grouper.

Red grouper, along with all marine organisms that rely on sound for communication, may be impacted by increasing levels of anthropogenic sound in the ocean (Coleman \& Koenig 2010). Oil and gas exploration, vessel traffic, scientific research and military activity 

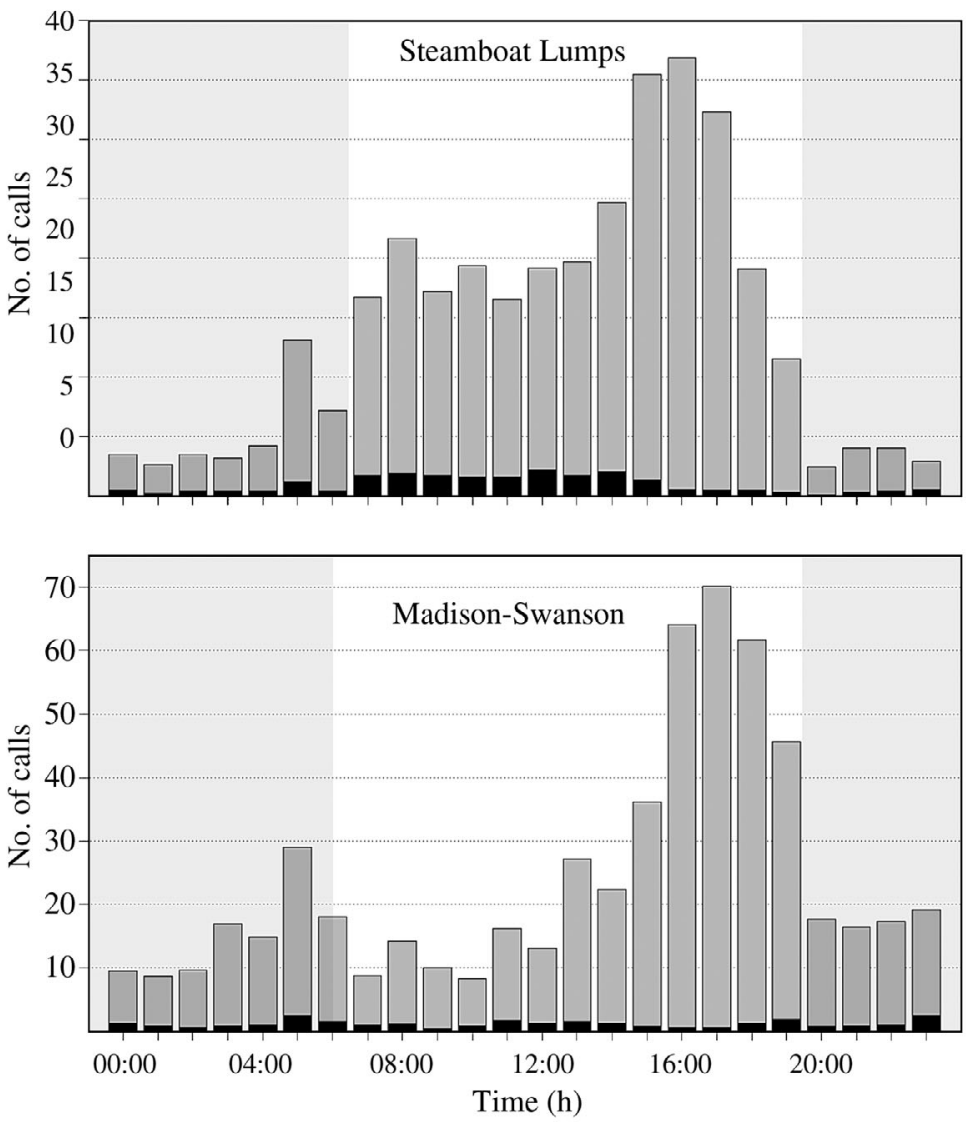

Fig. 12. Epinephelus morio. Periodicity of red grouper sound production by call type at Steamboat Lumps and Madison-Swanson marine reserves. Number of calls represents the mean number of short (gray) and pulse train (black) calls in all recordings from each 60 min time bin. Steamboat Lumps duty cycle was $2.5 \mathrm{~min}$ recordings every $10 \mathrm{~min}$; Madison-Swanson was $8 \mathrm{~min}$ recordings every $10 \mathrm{~min}$. Shaded areas represent night (sunrise: 05:50 h; sunset: 19:20 h)

all contribute acoustic energy to the marine environment (Hildebrand 2009). Low-frequency components attenuate least, and therefore travel farthest, so those species relying on low-frequency sounds to communicate-like red grouper-are most likely to be affected. Shipping noise has risen to such levels that global deep-water ambient noise has increased by 10-20 dB for frequencies below $300 \mathrm{~Hz}$ over the last $50 \mathrm{yr}$ (Ross 2005). At a minimum, this noise will likely cause an increase in signal masking below $300 \mathrm{~Hz}$. Masking occurs when noise levels increase (relative to a signal of interest) to the point that a receiver is no longer able to discriminate between the signal and background noise. Masking may interfere with social communication, predator avoidance, prey detection and other important signals. For example, Vasconcelos et al. (2007) demonstrated that vessel noise negatively affected hearing and conspecific communication in the Lusitanian toadfish Halobatrachus didactylus, and Codarin et al. (2009) reported that masking of conspecific sounds occurred in the presence of ship noise for brown meagre Sciaena umbra and Mediterranean damselfish Chromis chromis. Understanding the acoustic communication of red grouper will lay the foundation for future research to determine their susceptibility to noise pollution.

The results presented in this study offer new insight into the acoustic behavior of red grouper in their natural environment and provide a framework for future passive acoustic research. Better understanding of spatial and temporal patterns of red grouper reproductive activity will enable implementation of management practices aimed at optimizing spawning and recruitment, while at the same time maintaining a productive fishery. As a keystone species, red grouper play an important role in maintaining biological diversity and abundance. Given the value of red grouper, both in terms of human economics and ecosystem function, effective conservation and management strategies are crucial.

Acknowledgements. The authors thank the officers and crew of the MV 'Liberty Star', the NURC ROV pilots L. Horn and G. Taylor, and divers D. Kesling, S. Fowler, T. Dunmire and K. Dillon. We also thank E. Montie, P. Simard and C. Wall for assistance in the lab and field, and G. Gonzalez for design of camera housings. This research was supported by the US Department of Defense (DoD) through a National Defense Science and Engineering Graduate (NDSEG) Fellowship awarded to M.D.N., and the NURC at the University of North Carolina at Wilmington, NOAA grant \#NA030AR4300088 awarded to F.C.C., C.C.K. and D.A.M.

\section{LITERATURE CITED}

Amorim MCP, Fonseca PJ, Almada VC (2003) Sound production during courtship and spawning of Oreochromis mossambicus: male-female and male-male interactions. J Fish Biol 62:658-672

Beets J, Friedlander A (1998) Evaluation of a conservation strategy: a spawning aggregation closure for red hind, Epinephelus guttatus, in the U.S. Virgin Islands. Environ Biol Fishes 55:91-98

Brule T, Deniel C, Colas-Marrufo T, Sanches-Crespo M (1999) Red grouper reproduction in the southern Gulf of Mexico. Trans Am Fish Soc 128:385-402

Bullock LH, Smith GB (1991) Seabasses (Pisces: Serranidae). Mem Hourglass Cruises 8:1-206

Burgos JM, Sedberry GR, Wyanski DM, Harris PJ (2007) Life history of red grouper (Epinephelus morio) off the coasts of North Carolina and South Carolina. Bull Mar Sci 80: $45-65$

Codarin A, Wysocki LE, Ladich F, Picciulin M (2009) Effects of ambient and boat noise on hearing and communication in three fish species living in a marine protected area (Mira- 
mare, Italy). Mar Pollut Bull 58:1880-1887

Coleman FC, Koenig CC (2010) The effects of fishing, climate change, and other anthropogenic disturbances on red grouper and other reef fishes in the Gulf of Mexico. Integr Comp Biol 50:201-212

Coleman FC, Williams SL (2002) Overexploiting marine ecosystem engineers: potential consequences for biodiversity. Trends Ecol Evol 17:40-44

Coleman FC, Koenig CC, Collins LA (1996) Reproductive styles of shallow-water groupers (Pisces: Serranidae) in the eastern Gulf of Mexico and the consequences of fishing spawning aggregations. Environ Biol Fishes 47: 129-141

Coleman FC, Koenig CC, Huntsman GR, Musick JA and others (2000) Long-lived reef fishes: the grouper-snapper complex. Fisheries 25:14-20

Coleman FC, Baker PB, Koenig CC (2004) A review of Gulf of Mexico marine protected areas: successes, failures, and lessons learned. Fisheries 29:10-21

Coleman FC, Koenig CC, Scanlon KM, Heppell S, Heppell S, Miller MW (2010) Benthic habitat modification through excavation by red grouper, Epinephelus morio, in the northeastern Gulf of Mexico. Open Fish Sci J 3:1-15

Coleman FC, Scanlon KM, Koenig CC (in press) Groupers on the edge: shelf-edge spawning habitat in and around marine reserves of the northeastern Gulf of Mexico. Prof Geogr

Colin PL (1990) Preliminary investigations of reproductive activity of the jewfish, Epinephelus itajara (Pisces: Serranidae). Proc Gulf Caribb Fish Inst 43:138-147

Collins LA, Fitzhugh GR, Lombardi-Carlson LA, Lyon HM, Walling WT, Oliver DW (2002) Characterization of red grouper (Serranidae: Epinephelus morio) reproduction from the eastern Gulf of Mexico. NMFS-SEFSC Panama City Laboratory Contribution Series 2002-07, NMFS, Silver Spring, MD

Connaughton MA, Taylor MH (1995) Seasonal and daily cycles in sound production associated with spawning in the weakfish, Cynoscion regalis. Environ Biol Fishes 42: $233-240$

Cummings WC, Brahy BD, Spires JY (1966) Sound production, schooling, and feeding habits of the margate, Haemulon album Cuvier, off North Bimini, Bahamas. Bull Mar Sci 16:626-640

Donaldson TJ (1995) Courtship and spawning behavior of the pygmy grouper, Cephalopholis spiloparaea (Serranidae: Epinephelinae), with notes on $C$. argus and C. urodeta. Environ Biol Fishes 43:363-370

Erisman BE, Buckhorn ML, Hastings PA (2007) Spawning patterns in the leopard grouper, Mycteroperca rosacea, in comparison with other aggregating groupers. Mar Biol 151:1849-1861

Erisman BE, Craig MT, Hastings PA (2010) Reproductive biology of the Panama graysby Cephalopholis panamensis (Teleostei: Epinephelidae). J Fish Biol 76:1312-1328

Fish MP, Mowbray WH (1970) Sounds of Western North Atlantic Fishes. The Johns Hopkins Press, Baltimore, MD

Gaines SD, White C, Carr MH, Palumbi SR (2010) Designing marine reserve networks for both conservation and fisheries management. Proc Natl Acad Sci USA 107: 18286-18293

Gulf of Mexico Fishery Management Council (GMFMC) (2008) Final Reef Fish Amendment 30B. Gulf of Mexico Fishery Management Council, Tampa, FL

Halpern BS (2003) The impact of marine reserves: Do reserves work and does reserve size matter? Ecol Appl 13(Suppl):117-137
Halpern BS, Warner RR (2002) Marine reserves have rapid and lasting effects. Ecol Lett 5:361-366

Hazlett B, Winn HE (1962) Sound producing mechanism of the Nassau grouper, Epinephalus striatus. Copeia 1962: $447-449$

Hereu B, Diaz D, Pasqual J, Zabala M, Sala E (2006) Temporal patterns of spawning of the dusky grouper Epinephelus marginatus in relation to environmental factors. Mar Ecol Prog Ser 325:187-194

Hildebrand JA (2009) Anthropogenic and natural sources of ambient noise in the ocean. Mar Ecol Prog Ser 395:5-20

Johnson AK, Thomas P, Wilson RR Jr (1998) Seasonal cycles of gonadal development and plasma sex steroid levels in Epinephelus morio, a protogynous grouper in the eastern Gulf of Mexico. J Fish Biol 52:502-518

> Johnston CE, Johnson DL (2000) Sound production during the spawning season in cavity-nesting darters of the subgenus Catonotus (Percidae: Etheostoma). Copeia 2000:475-481

Jory DE, Iversen ES (1989) Species profiles: life histories and environmental requirements of coastal fishes and invertebrates (South Florida) - black, red and Nassau groupers. US Fish and Wildlife Service Biological Report 82(11110). US Army Corps of Engineers, TR EL-82-4. US Department of the Interior, Slidell, LA

Koenig CC, Coleman FC, Grimes CB, Fitzhugh GR, Scanlon KM, Gledhill CT, Grace M (2000) Protection of fish spawning habitat for the conservation of warm-temperate reeffish fisheries of shelf-edge reefs of Florida. Bull Mar Sci 66:593-616

- Ladich F (1997) Agonistic behavior and significance of sounds in vocalizing fish. Mar Freshw Behav Physiol 29:87-108

- Lobel PS (1992) Sounds produced by spawning fishes. Environ Biol Fishes 33:351-358

> Locascio JV, Mann DA (2008) Diel periodicity of fish sound production in Charlotte Harbor, Florida. Trans Am Fish Soc 137:606-615

Luczkovich JJ, Sprague MW, Johnson SE, Pullinger RC (1999) Delimiting spawning areas of weakfish Cynoscion regalis (Family Sciaenidae) in Pamlico Sound, North Carolina using passive hydroacoustic surveys. Bioacoustics 10: $143-160$

Mackie M (2007) Reproductive behavior of the halfmoon grouper, Epinephelus rivulatus, at Ningaloo Reef, Western Australia. Ichthyol Res 54:213-220

Malavasi S, Valerio C, Torricelli P (2009) Courtship sounds and associated behaviours in the Canestrini's goby Pomatoschistus canestrinii. J Fish Biol 75:1883-1887

Mann DA, Lobel PS (1995) Passive acoustic detection of sounds produced by the damselfish, Dascyllus albisella (Pomacentridae). Bioacoustics 6:199-213

Mann DA, Locascio JV (2008) Acoustic communication in fishes. Bioacoustics 17:43-45

Mann DA, Bowers-Altman J, Rountree RA (1997) Sounds produced by the striped cusk-eel Ophidion marginatum (Ophidiidae) during courtship and spawning. Copeia 1997: 610-612

Mann DA, Locascio JV, Coleman FC, Koenig CC (2009) Goliath grouper Epinephelus itajara sound production and movement patterns on aggregation sites. Endang Species Res 7:229-236

Martin K, Samoilys MA, Hurd AK, Meliane I, Lundin CG (2007) Experiences in the use of marine protected areas with fisheries management objectives: a review of case studies. In: Report and documentation of the Expert Workshop on Marine Protected Areas and Fisheries Management: review of issues and considerations, FAO Fisheries Report No 825, Rome, p 21-108 
Maruska KP, Mensinger AF (2009) Acoustic characteristics and variations in grunt vocalizations in the oyster toadfish Opsanus tau. Environ Biol Fishes 84:325-337

McKibben JR, Bass AH (1998) Behavioral assessment of acoustic parameters relevant to signal recognition and preference in a vocal fish. J Acoust Soc Am 104:3520-3533

Moe MA Jr (1966) Tagging fishes in Florida offshore waters. State Fla Board Conserv Div Salt Water Fish Tech Ser 49: $1-40$

Moe MA Jr (1969) Biology of the red grouper Epinephelus morio (Valenciennes) from the eastern Gulf of Mexico. Fla Dept Nat Resour Mar Res Lab Prof Pap Ser 10:1-95

Mok HK, Gilmore RG (1983) Analysis of sound production in estuarine fish aggregations of Pogonias cromis, Bairdiella chrysoura, and Cynoscion nebulosus (Sciaenidae). Bull Inst Zool Acad Sin 22:157-186

Moulton JM (1958) The acoustical behavior of some fishes in the Bimini area. Biol Bull 114:357-374

Myrberg AA Jr (1972) Social dominance and territoriality in the bicolor damselfish, Eupomacentrus partitus (Poey) (Pisces: Pomacentridae). Behaviour 41:207-231

Myrberg AA Jr, Mohler M, Catala JD (1986) Sound production by males of a coral reef fish (Pomacentrus partitus): its significance to females. Anim Behav 34:913-923

Nemeth RS (2005) Population characteristics of a recovering US Virgin Islands red hind spawning aggregation following protection. Mar Ecol Prog Ser 286:81-97

NMFS (National Marine Fisheries Service) (2011) Annual commercial landing statistics. www.st.nmfs.noaa.gov/st1/ commercial/landings/annual_landings.html

Ross D (2005) Ship sources of ambient noise. IEEE J Oceanic Eng 30:257-261

Sadovy Y, Colin PL, Domeier ML (1994) Aggregation and spawning in the tiger grouper, Mycteroperca tigris (Pisces: Serranidae). Copeia 1994:511-516

Scanlon KM, Coleman FC, Koenig CC (2005) Pockmarks on the outer shelf in the northern Gulf of Mexico: gas-release features or habitat modifications by fish? Am Fish Soc Symp 41:301-312

Sirovic A, Cutter GR, Butler JL, Demer DA (2009) Rockfish sounds and their potential use for population monitoring in the Southern California Bight. ICES J Mar Sci 66: 981-990

Steinberg JC, Kronengold M, Cummings WC (1962) Hydrophone installation for the study of soniferous marine animals. J Acoust Soc Am 34:1090-1095

Steinberg JC, Cummings WC, Brahy BD, MacBain Spires JY (1965) Further bio-acoustic studies off the west coast of North Bimini, Bahamas. Bull Mar Sci 15:942-963

- Vasconcelos RO, Amorim MCP, Ladich F (2007) Effects of ship noise on the detectability of communication signals in the Lusitanian toadfish. J Exp Biol 210:2104-2112

Winn HE, Marshall JA, Hazlett B (1964) Behavior, diel activities, and stimuli that elicit sound production and reactions to sounds in the longspine squirrelfish. Copeia 1964: $413-425$

Appendix 1. Statistical data on sound production in red grouper Epinephelus morio

Table A1. Epinephelus morio. Descriptive statistics for red grouper calls. Inter-pulse intervals were measured as the time from the first positive peak of one pulse to the first positive peak of the subsequent pulse. CV calculated as $(100 \times \mathrm{SD}) / \mathrm{mean}$; G: growl; IP: introductory pulse; PT: pulse train; SPL: received RMS sound pressure level

\begin{tabular}{|c|c|c|c|c|c|c|}
\hline Call type & Measure & Mean & $\mathrm{SD}$ & Min. & Max. & $\mathrm{CV}(\%)$ \\
\hline \multirow{10}{*}{ Short $(n=100)$} & Peak frequency $(\mathrm{Hz})$ & 150 & 51 & 39 & 190 & 34 \\
\hline & $6 \mathrm{~dB}$ bandwidth $(\mathrm{Hz})$ & 148 & 57 & 3 & 260 & 38 \\
\hline & Call duration (s) & 1.9 & 0.3 & 1.4 & 2.8 & 14.9 \\
\hline & Pulses call ${ }^{-1}$ & 4 & 1 & 3 & 7 & 19 \\
\hline & Mean IP duration (ms) & 161 & 33 & 67 & 244 & 20 \\
\hline & Mean IP inter-pulse interval (ms) & 355 & 51 & 272 & 440 & 14 \\
\hline & G pulse duration (s) & 0.7 & 0.2 & 0.5 & 1.2 & 21.0 \\
\hline & G peak frequency $(\mathrm{Hz})$ & 112 & 56 & 35 & 237 & 50 \\
\hline & Peak amplitude (mV) & 114 & 118 & 13 & 733 & 104 \\
\hline & Received SPL (dB re $1 \mu \mathrm{Pa}$ RMS) & 124 & 6 & 110 & 142 & 5 \\
\hline \multirow[t]{12}{*}{ Pulse train $(n=16)$} & Peak frequency $(\mathrm{Hz})$ & 131 & 63 & 13 & 185 & 49 \\
\hline & $6 \mathrm{~dB}$ bandwidth $(\mathrm{Hz})$ & 118 & 62 & 30 & 179 & 53 \\
\hline & Call duration (s) & 7.7 & 5.4 & 2.5 & 22.4 & 70.9 \\
\hline & Pulses call ${ }^{-1}$ & 33 & 16 & 11 & 57 & 50 \\
\hline & Mean IP duration (ms) & 153 & 43 & 92 & 224 & 28 \\
\hline & Mean IP inter-pulse interval (ms) & 370 & 43 & 286 & 448 & 12 \\
\hline & G pulse duration (s) & 1.8 & 0.2 & 1.5 & 2.2 & 11.8 \\
\hline & G peak frequency $(\mathrm{Hz})$ & 89 & 55 & 35 & 202 & 62 \\
\hline & Mean PT duration (ms) & 113 & 42 & 50 & 195 & 37 \\
\hline & Mean PT inter-pulse interval (ms) & 201 & 76 & 105 & 391 & 38 \\
\hline & Peak amplitude $(\mathrm{mV})$ & 88 & 49 & 24 & 184 & 56 \\
\hline & Received SPL (dB re $1 \mu \mathrm{Pa}$ RMS) & 122 & 4 & 116 & 128 & 3 \\
\hline
\end{tabular}


Table A2. Epinephelus morio. Sound properties and observed behaviors of red grouper. Representative examples of behaviors can be seen in the supplementary videos at www.int-res.com/articles/suppl/b012p097_supp/. DBC: direct body contact; F: female; M: male; PT: pulse train; SPL: sound pressure level

\begin{tabular}{|c|c|c|c|c|c|c|c|c|}
\hline Recorder & $\begin{array}{l}\text { Time } \\
\text { (h) }\end{array}$ & Type & $\begin{array}{c}\text { Received SPL } \\
\text { (dB re } 1 \mu \mathrm{Pa} \text { RMS) }\end{array}$ & $\begin{array}{c}\text { Peak frequency } \\
(\mathrm{Hz})\end{array}$ & Pulses & $\begin{array}{l}\text { Duration } \\
\text { (s) }\end{array}$ & Sex & Behavior \\
\hline SL4 & $18: 41$ & Short & 124 & 43.1 & 5 & 2.1 & M & Patrol \\
\hline SL5 & $17: 01$ & Short & 120 & 176.6 & 4 & 1.8 & M & Patrol \\
\hline SL5 & $17: 04$ & Short & 122 & 176.6 & 3 & 1.5 & M & Patrol \\
\hline SL5 & $17: 57$ & Short & 125 & 176.6 & 4 & 1.9 & M & Patrol \\
\hline SL5 & $18: 13$ & Short & 131 & 176.6 & 5 & 1.8 & M & Patrol \\
\hline SL6 & $17: 14$ & Short & 123 & 180.9 & 3 & 1.4 & $\mathrm{M}$ & Patrol \\
\hline SL6 & $18: 24$ & Short & 119 & 176.6 & 4 & 2 & M & Patrol \\
\hline SL6 & $18: 26$ & Short & 120 & 176.6 & 4 & 1.5 & M & Patrol \\
\hline SL6 & $18: 28$ & Short & 124 & 180.9 & 5 & 1.8 & $\mathrm{M}$ & Patrol \\
\hline SL6 & $18: 30$ & Short & 120 & 176.6 & 4 & 1.8 & M & Patrol \\
\hline SL6 & $18: 35$ & Short & 122 & 180.9 & 5 & 1.9 & M & Patrol \\
\hline SL6 & $18: 48$ & $\mathrm{PT}$ & 120 & 176.6 & 14 & 3 & M & Patrol \\
\hline SL2 & $18: 14$ & Short & 126 & 47.4 & 5 & 2.1 & $\mathrm{M}$ & Color change \\
\hline SL5 & $18: 18$ & Short & 125 & 180.9 & 5 & 1.8 & $\mathrm{M}$ & Color change \\
\hline SL8 & $18: 01$ & $\mathrm{PT}$ & 116 & 159.3 & 15 & 3.8 & $\mathrm{M}+\mathrm{F}$ & Color change \\
\hline SL5 & $16: 55$ & Short & 122 & 180.9 & 3 & 1.6 & $\mathrm{M}+\mathrm{F}$ & Courtship \\
\hline SL5 & $17: 58$ & Short & 128 & 180.9 & 5 & 2.3 & $\mathrm{M}+\mathrm{F}$ & Courtship \\
\hline SL6 & $16: 46$ & Short & 126 & 176.6 & 4 & 1.6 & $\mathrm{M}+\mathrm{F}$ & Courtship \\
\hline SL6 & $16: 48$ & Short & 119 & 137.8 & 3 & 1.6 & $\mathrm{M}+\mathrm{F}$ & Courtship \\
\hline SL6 & $16: 51$ & Short & 120 & 180.9 & 3 & 1.6 & $\mathrm{M}+\mathrm{F}$ & Courtship \\
\hline SL6 & $16: 52$ & Short & 120 & 180.9 & 4 & 1.6 & $\mathrm{M}+\mathrm{F}$ & Courtship \\
\hline SL1 & $18: 30$ & Short & 124 & 38.8 & 5 & 2.3 & $\mathrm{M}+\mathrm{F}$ & Courtship + DBC \\
\hline SL5 & $17: 49$ & Short & 125 & 176.6 & 4 & 1.8 & $\mathrm{M}+\mathrm{F}$ & Courtship + DBC \\
\hline SL6 & $16: 20$ & $\mathrm{PT}$ & 127 & 180.9 & 16 & 3.4 & $\mathrm{M}+\mathrm{F}$ & Courtship + DBC \\
\hline SL6 & $16: 49$ & $\mathrm{PT}$ & 119 & 176.6 & 28 & 3.6 & $\mathrm{M}+\mathrm{F}$ & Courtship + DBC \\
\hline
\end{tabular}

Editorial responsibility: Hans Heinrich Janssen, Oldendorf/Luhe, Germany
Submitted: October 13, 2010; Accepted: January 27, 2011 Proofs received from author(s): April 13, 2011 